\title{
Contemporary Management Accounting Practices and Managerial Performance Amongst the Malaysian Co-operatives Sector
}

\author{
Sharul Effendy Janudin ${ }^{1}$, Hazianti Abdul Halim ${ }^{1}$, Nurul Fadly Habidin ${ }^{1} \&$ Farahaini Mohd Hanif ${ }^{2}$ \\ ${ }^{1}$ Universiti Pendidikan Sultan Idris, Tanjung Malim, Malaysia \\ ${ }^{2}$ Institut Koperasi Malaysia, Malaysia \\ Correspondence: Sharul Effendy Janudin, Universiti Pendidikan Sultan Idris, Tanjung Malim, Malaysia. E-mail: \\ sharul@fpe.upsi.edu.my
}

Received: October 10, 2019

Accepted: November 5, 2019

Online Published: December 23, 2019

doi:10.5430/rwe.v10n5p129

URL: https://doi.org/10.5430/rwe.v10n5p129

\begin{abstract}
Co-operatives in Malaysia have urgent jobs in creating business frameworks, and making it workable for the nation to join the worldwide co-operatives society and refined economies. Thus, top management in Malaysian cooperatives aggressively design and implement their strategic plan through strategic accounting procedures in leadership. The purpose of this research is to examine the association between the contemporary management accounting practices (MAP) and managerial performance in the Malaysian' co-operative sector. Management team from the 100 leading co-operatives in Malaysia were the respondents. Descriptive on the adoption level and its relationship with the managerial performance has been analysed. The finding indicates the level of contemporary MAP is high and there is significant relationship between contemporary MAP and managerial performance among Malaysian Co-operatives. This research offers a exclusive details investigation of the contemporary MAP and an signal of upcoming trends.
\end{abstract}

Keywords: management accounting practices, managerial performance, co-operatives

\section{Introduction}

Development of recent issues about study on the practicality of management accounting tools has increasingly led to the individual perspectives as a comparison from the organizational perspectives. In addition, low adoption levels of management accounting methods lead to researcher interested in investigating management accounting innovations in serving different business entities. Resource based view theory (RBV) indicates that competitive advantage and performance outcome are the result of organization-specific resources and capacities that other competitors expensive to copy (Barney, 1997; Barney \& Wright, 1998; Barney et al., 2001; Rumelt, 1991; Wernerfelt, 1984). If they have certain unique features, these resource and capacities can be significant variables of sustainable competitive advantage and superior company performance

The co-operatives sector is particularly new to the examination of contemporary MAP. The introduction of National Cooperative Policy 2011-2010 is an extension of The National Cooperative Policy 2002 - 2010 by charting five strategic thrusts in smoothing the co-operative movement. Many organizations such as Malaysian National Co-operative Movement (ANGKASA) and Malaysia Co-operative Societies Commission of Malaysia (SKM) are executing proactive action in tandem with the National Cooperative Policy 2011-2010 especially through economic activities. As a measurement mechanism, Malaysia Co-operative Societies Commission of Malaysia (SKM) releases a profile of top 100 co-operatives in Malaysia since 2009. The assessment process is very objective base on financial and nonfinancial indicator. Further investigation on the 100 list has shown there were not so much changes in terms of co-operative selected each year. For entrepreneurial co-operative, management accounting may aid as a important capability for going global (Mitter \& Hiebl, 2017). Changes in leadership through the election of co-operatives board member work as a catalyst to the consequences of the introduction of contemporary MAP ( Subair, \& Oriogu, 2016; Leotta, Rizza, \& Ruggeri, 2017).

At point of time, the research on the implementation and success of contemporary MAP is still lacking pertaining to the model applied amongst successful co-operatives. This research enhances to the current information of contemporary MAP amongst 100 best co-operatives in Malaysia. Specifically, this research aims to investigate the adoption of contemporary management accounting (CMA) techniques in Malaysian Co-operatives sector and to 
investigate the relationship between contemporary management accounting (CMA) techniques on Malaysian Co-operatives managerial performance.

\section{Literature Review and Hypothesis Development}

\subsection{Contemporary Management Accounting}

MAP are the techniques use to supply organisations with pertinent information for the effective and resourceful. It also refers to management of resources so as to improve value to customers and stakeholders. In the literature, discussions on MAP are classified into two mainstreams: traditional and contemporary MAP. Traditional MAP are those MAP that are financial and internal in alignment; short-range focused; and include random cost provisions such as cost benefit analysis, return on investment, standard costing and variance analysis, (Pavlatos \& Paggios, 2008).

Critique and comments on traditional MAP are due to slimness and failure to meet information requirements to empower change and business challenges. Hence, contemporary MAP were established ( $\mathrm{Wu}$, Boateng, \& Drury, 2007) and activity based management, cost behaviour analysis, performance measurement system and benchmarking are example of contemporary MAP that organisations commonly use. These management accounting emphasis quality, practices accentuate speed, quality, integrate cost management and improve customer satisfaction (Abdel-Maksoud, Abdallah, \& Youssef, 2012; Ambrose, Etim, \& Enagu, 2016), and are measured important for the current vibrant business/operating atmosphere. MAP are expected to adapt and evolve with changing of business activities. Top management team knowledge, team based structures and information system flexibility have been identified as factors impacted management accounting effectiveness (Yigitbasioglu, 2017).

\subsection{Contemporary Management Accounting Practices}

According to Abdel-Kader and Luther (2006a), management accounting has evolved in four stages; prior to 1950 focus on cost determination and financial control, by 1965 - provision of information for management planning, by 1985 - focus on the reduction of waste in resources, and by 1995 - attention to the generation of value through the effective use of resources. Many management accounting tools have been introduced to support the evolution. Even though there are many tools in management accounting, this study only takes costing system, budgeting system, strategic analysis, information for decision making and performance measurement as variables to be analyse.

\subsubsection{Costing System}

Costing system or cost accounting is the process of recording, classifying, summarizing, and allocating various courses of action to support cost control activities. It is also an accounting methods that aims to capture company's cost of production by assessing the input cost. A proper costing techniques will assist management in making decisions and in the planning and control of an organization. Cost accounting varies by business nature, since there are no standards for how they are to be constructed.

\subsubsection{Budgeting System}

Planning and budgeting systems are important element of financial results control system. A budget defines as a quantitative expression of a plan of action by the organization for a specified period. Overall objectives of the organization are translated in to details by mutually agreement amongst organization members' in budget preparation. To do this effectively requires top management support, cooperative and teamwork. The behavioral aspects of budgeting are supreme importance because deal with human attitude and behavior. Budget provides clear guidelines for managers to translate organizational objectives into specific task. It helps managers to communicate and coordinate attention directed to areas of most critical.

\subsubsection{Strategic Analysis}

In the literature, strategic management accounting (SMA) is thought to be a leeway and a different coordination that offers a comprehensive external method towards management accounting practice from its ancient tradition towards a tactical improvement outside the norms (Oboh \& Ajibolade, 2017). SMA incorporates a wider emphasis and longer-term viewpoint than the superior part of management accounting. Conservatively, management accounting has concentrated on the provision of history financial information. This is steadily swapped by a new approach that takes a more active information arising from curiosity in aggressive management information that produces significant value for the organization (Aver \& Cadez, 2009). These advanced approach combine both financial and non-financial data, past and future, assemble from external and internal sources (Kalkhouran, Rasid, Sofian, \& Nedaei, 2015; Joshua, 2016). 


\subsubsection{Information for Decision Making}

Management accounting is a critical function in organization. If management accounting functions fail, it can lead to large financial loses, reputation damage, and possibly even to organizational (Brauers, 2018). It involves process of supplying the managers with relevant information. It combines financial and non-financial information. In a broader perspectives, the information will be use to allocate resources, making decision, monitoring and evaluating performance. Information in management accounting is retrospective by providing feedback about past operations and prospective by forecasting future events. Ideally, a good management accounting information can become a source of competitive advantage for organization.

An accurate information on cost is the main element in developing strategy as well as to monitor end result of strategy implementation. Product price, product capacity planning, variance analysis, performance management and variance analysis are amongst the decision to be made and it requires relevant information. The evolution of management accounting from cost determination to planning has seen the introduction of cost-volume-profit analysis, product profitability analysis, customer profitability analysis and variance analysis.

In advance, managers usually develop decision model for choosing among different alternative. Combination of quantitative and qualitative analysis will be utilized in designing decision model. Generally, decision making process involves five steps: identify the problem and uncertainties, obtaining information, make predictions about the future, choosing the best alternatives and implement the decision. It is important in decision making process to recognize two characteristics of relevance information: occur in the future and differ among the alternative courses of action.

\subsubsection{Performance Measurement}

Performance measurement system plays strategic role in most organization by contributing relevant information. Economic, technology and social changes are driving PMS to be contemporary. Despite its objective to produce constructive changes in the organisational culture, understanding stakeholder needs and complete strategic management roles, the function of PMS have evolved to include unceasing enhancement, organisational culture and change administration (Pinheiro de Lima et al., 2013). The qualities and use of PMS have substantial indirect effects on the relationship between the differentiation plan, eco-friendly competitiveness and organisational performance (Amizawati, 2011; Hussain et al., 2017).

Currently, the use of financial and non-financial performance measures are the famous constructs of contemporary performance measurement system. Furthermore, contemporary PMS must be link to the organisation's strategy. Balanced scorecard is example of contemporary PMS because it supports the use of a range of financial and non-financial measures (Cheng et al., 2007). It assist organisation to transform its strategies in executable results by merging resources and financial ability. Franco-Santos et al. (2012) claimed that a contemporary PMS exists if financial and non-financial performance methods are used to operationalize tactical plan Henri (2010) raises the need of interval review on measures to reflect business changes. Therefore, three elements should be applied in outlining contemporary PMS: comprehensive, strategic and dynamic. On top of that, clear link between strategic objectives and reflect the surrounding environments also the components of contemporary PMS.

\subsection{Managerial Performance}

Managerial performance is debatably the most important success factor in organizational study. Yet, despite broad research in to the concept of managerial performance, there is still no mutual framework fundamental of managers' performance. This is also due to leadership and management roles overlap, as most leaders find themselves managing at times while most managers show some leadership skills. In Kenya, managerial actions and initiative are important because leadership is the main challenge to minimize co -operative societies grieve common problems associated with weak regulation, deprived financial management, leadership, governance and political meddling (Kinyuira, 2015; Ngara, 2017).

In the literature, managers' work performance has changed through many discussions in the literature. Due to performance is multidimensional, managers are expected to be evaluated from two performance facet; task performance and contextual performance. Task performance for managers is defined as any action taken to help the organization to function smoothly. Any behaviors that lead to the organization's effectiveness by developing a good situation in which task performance can occur is defined as contextual performance. As a result of technological advancements and borderless competition, managerial performance dynamically change and its count for the manager's potential of planning, organizing, directing, controlling and staffing. Chung and Su (2012) highlighted managers must be good at investigation, appraisal, negotiation and representation (Geldres-Weiss et al., 2018). 


\subsection{Contemporary Management Accounting Practices and Managerial Performance}

Managing co-operative is very challenging. Top management must ensure member's welfare and co-operative sustainability always become the goal. Therefore, business performance should be plan thoroughly and the execution of the plan being monitored closely. Thus, knowledge of contemporary MAP are crucial for managers as it has significant relationship with managerial performance. Santos, Lavarda, and Marcello (2014) found that there is significant relationship between cost management knowledge and managers' performance in Southern Brazil. Management accounting is applied tools to align managers' personal interests with organizational goals. In Palu Indonesia, knowledge and application of budgeting positively influence managers performance (Usman et al., 2016). Ghasemi, Mohamad, Karami, Bajuri, and Asgharizade (2016) uncovered the existence relationship between management accounting system and managerial performance in Iran financial organizations.

A good co-operative should have good managers with contemporary management accounting knowledge. Costing system, budgeting system, strategic analysis, decision making process and performance measurement amongst the critical tools for management purposes. These will helps the managers performs their managerial functions wisely. Managers with high competency and efficiency is one of the requirement for organizational success. It is a challenge for the managers for making management accounting tools effectively lies in an appropriate, balanced and relevant (Ates, Garengo, Cocca, \& Bititci, 2013). Therefore, six hypotheses has been developed for this study as shown in Figure 1 .

H1 There is a significant relationship between costing system and managerial performance among Malaysian Co-operatives

H2 There is a significant relationship between budgeting system and managerial performance among Malaysian Co-operatives

H3 There is a significant relationship between strategic analysis and managerial performance among Malaysian Co-operatives

H4 There is a significant relationship between information for decision making and managerial performance among Malaysian Co-operatives

H5 There is a significant relationship between performance measurement and managerial performance among Malaysian Co-operatives

H6 There is a significant relationship between contemporary MAP and managerial performance among Malaysian Co-operatives

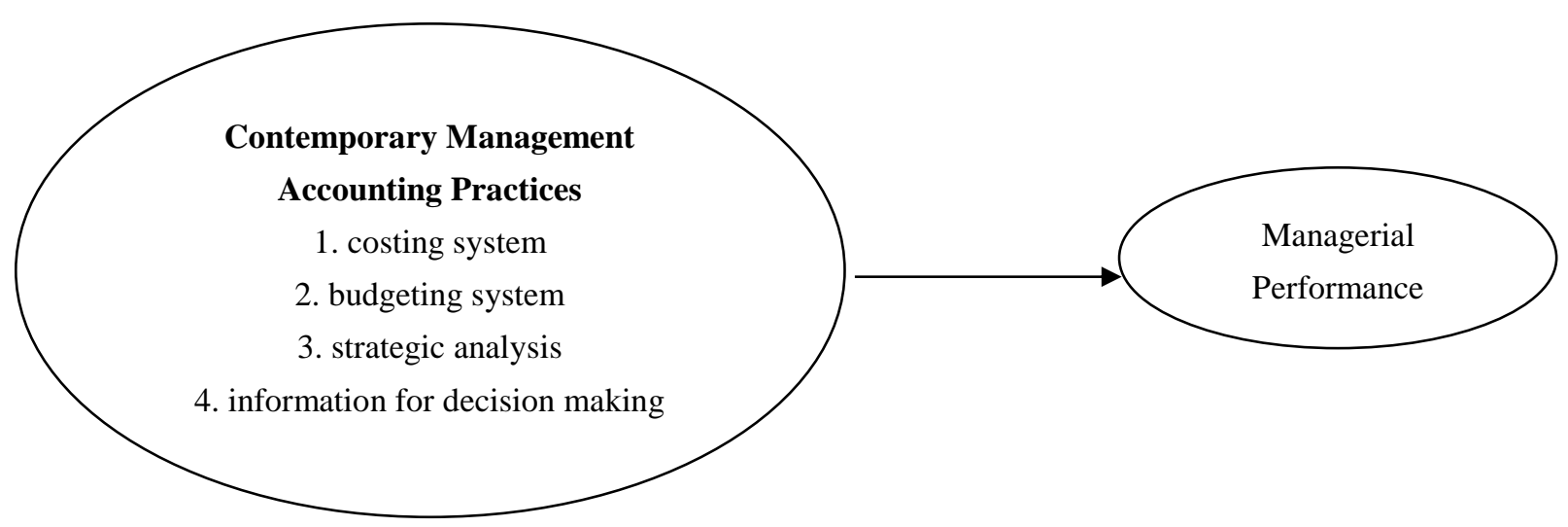

Figure 1. Research framework

\section{Methodology}

\subsection{Sample and Data Collection}

Data gathered through a survey conducted in Malaysia were used to test the hypothesis. A survey is organised covering 100 best co-operatives as listed in directory prepared by Malaysia Co-operatives Societies Commission for 2018. Pilot test is run with an accountants and managers to filter the aim and focal of the survey. Accountants who 
have vast experience deal with MAP were interviewed to make sure the questionnaires items are easy to understand.

Respondents were asked to specify whether co-operative has used each management accounting practice. Respondents are also asked to level of their managerial performance. Sampling frame are managers from Malaysian Best 100 Cooperatives and selection base on random sampling method. Each selected co-operatives received three sets of questionnaires and phone call has been made by the researcher in order to explain the suitability of respondents. So, total 300 respondents were the target population. The geographical location of best 100 co-operatives in Malaysia is as in Table 1.

Table 1. No of cooperatives and states

\begin{tabular}{ll}
\hline STATES & NO OF COOPERATIVES \\
\hline Johor & 14 \\
\hline Kedah & 4 \\
\hline Kelantan & 6 \\
\hline Pahang & 18 \\
\hline Perak & 9 \\
\hline Perlis & 1 \\
\hline Pulau Pinang & 6 \\
\hline Sabah & 4 \\
\hline Sarawak & 4 \\
\hline Selangor & 3 \\
\hline Terengganu & 6 \\
\hline Wilayah & 25 \\
Persekutuan & \\
\hline Total & $\mathbf{1 0 0}$
\end{tabular}

\subsection{Variable Measurement}

The 27 MAP are clustered in five categories. These are: costing system, budgeting system, strategic analysis, information for decision making and performance measurement and listed in Table 2.

Table 2. Measurement of variables

\begin{tabular}{llll}
\hline Variables & No of Items & Source & Scale \\
\hline Costing system & 7 & Chand and Ambardar (2013), \\
\hline Budgeting system & 5 & Pavlatos and Paggios (2008), \\
\hline Strategic analysis & Hansen and Mowenne 1-lowest extension of \\
\hline Information for decision making & 5 & (2007), R. H. Chenhall \& use, $7-$ highest \\
Performance measurement & 6 & $\begin{array}{l}\text { Langfield-Smith (1998), extension of use } \\
\text { (Ittner, Larcker, \& Rajan, } \\
\text { 1997) }\end{array}$ \\
\hline
\end{tabular}

The instruments developed by Mahoney et. al (1965) were used to evaluate eight dimensions of managerial performance. The managers or heads of each co-operative were asked to rate their own perceived performance on eight sub-dimensions and rate the overall management performance. The scale used was 1 - extremely low to 7 extremely high. This instrument has been frequently and widely used in numerous behavioral accounting studies (e.g. Chung \& Su, 2012; Ghasemi, Mohamad, Karami, Bajuri, \& Asgharizade, 2016; Hammad et al., 2013; Lau, 2015).

\section{Results}

\subsection{Descriptive Statistics}

A total 300 of questionnaires were mailed out; 123 which were returned. 17 invalid replies were deleted and only 
106 valid responses used for further analysis. The characteristics of the respondents are detailed out in table 3 . Most of the respondents that were sampled working as executive $(40.6 \%)$ and have 4 to 6 years working experience $(36.8 \%)$ at the respective co-operatives. As proven by the figures, respondents are qualified source of information for the study, with reliable working experience and exposed with contemporary MAP.

Table 3. Sample data and respondents' demographic

\begin{tabular}{|c|c|c|}
\hline & Frequency $(\mathrm{N}=106)$ & Percentage \\
\hline \multicolumn{3}{|l|}{ Gender } \\
\hline Male & 57 & 53.8 \\
\hline Female & 49 & 46.2 \\
\hline \multicolumn{3}{|l|}{ Age } \\
\hline 20 to 30 years & 18 & 17 \\
\hline 31 to 40 years & 38 & 35.8 \\
\hline 41 to 50 years & 24 & 22.6 \\
\hline Above 50 years & 26 & 24.5 \\
\hline \multicolumn{3}{|l|}{ Academic Qualification } \\
\hline $\begin{array}{l}\text { Malaysian Certificate of Education (Sijil } \\
\text { Pelajaran Malaysia) }\end{array}$ & 14 & 13.2 \\
\hline Diploma & 21 & 19.8 \\
\hline Bachelors Degree & 43 & 40.6 \\
\hline Masters Degree & 23 & 21.7 \\
\hline Doctorates Degree & 5 & 4.7 \\
\hline \multicolumn{3}{|l|}{ Position } \\
\hline Chairman & 6 & 5.7 \\
\hline Secretary & 7 & 6.6 \\
\hline Bursary & 10 & 9.4 \\
\hline Boards Member & 8 & 7.5 \\
\hline Manager & 32 & 30.2 \\
\hline Executive & 43 & 40.6 \\
\hline \multicolumn{3}{|l|}{$\begin{array}{l}\text { Working experience with respective } \\
\text { co-operative }\end{array}$} \\
\hline $1-3$ years & 19 & 17.9 \\
\hline $4-6$ years & 39 & 36.8 \\
\hline $7-9$ years & 16 & 15.1 \\
\hline $10-12$ years & 16 & 15.1 \\
\hline Above 12 years & 16 & 15.1 \\
\hline
\end{tabular}

Items with low reliability and validity were eliminated prior conducting further analysis. Cronbach's $\alpha$ was used to measure the internal consistency of various constructs of the questionnaire Nunnally and Bernstein (1994). Cronbach's $\alpha$ for individual constructs is shown in table 4 . All constructs were above 0.7 , which indicates that it has a satisfactory level of reliability (Hair, Black, \& Anderson, 2010). 
Table 4. Measures of survey reliability

\begin{tabular}{ll}
\hline & Cronbach's $\boldsymbol{\alpha}$ \\
\hline Costing system & 0.768 \\
Budgeting system & 0.713 \\
Strategic analysis & 0.875 \\
Information for decision making & 0.693 \\
Performance measurement & 0.746 \\
Managerial Performance & 0.840 \\
\hline
\end{tabular}

Table 5 shows the result of contemporary MAP among the co-operatives in Malaysia. It is clearly shows that the level of adoption is high which the lowest is costing system (mean $=4.888$ ). Generally it can be concluded that management accounting tools are needed in managing co-operatives regardless the revenue's size.

Table 5. Means for contemporary MAP

\begin{tabular}{lll}
\hline & Mean & Standard Deviation \\
\hline Costing system & 4.888 & 0.8514 \\
Budgeting system & 5.236 & 0.7663 \\
Strategic analysis & 5.142 & 1.1547 \\
Information for decision making & 5.283 & 0.8013 \\
Performance measurement & 5.401 & 0.6869 \\
\hline
\end{tabular}

Table 6 presents the correlation coefficient matrices of all the variables. All the independent variables (costing system, budgeting system, strategic analysis, information for decision making, performance measurement) are positively associated to the managerial performance at significant value of $p<0.001$. The results in table 3 shows that contemporary MAP and managerial performance is moderately correlated $(\mathrm{r}=0.515, \mathrm{p}<0.001)$.

Table 6. Correlations among the variables

\begin{tabular}{|c|c|c|c|c|c|c|c|c|}
\hline & & $\begin{array}{l}\text { Costing } \\
\text { System }\end{array}$ & $\begin{array}{l}\text { Budgeting } \\
\text { System }\end{array}$ & $\begin{array}{l}\text { Strategic } \\
\text { Analysis }\end{array}$ & $\begin{array}{l}\text { Information for } \\
\text { Decision Making }\end{array}$ & $\begin{array}{c}\text { Performance } \\
\text { Measurement System }\end{array}$ & $\begin{array}{c}\text { Contemporary } \\
\text { MAP }\end{array}$ & $\begin{array}{l}\text { Managerial } \\
\text { Performance }\end{array}$ \\
\hline \multirow[t]{3}{*}{ Costing System } & Pearson Correlation & 1 & & & & & & \\
\hline & Sig. (2-tailed) & & & & & & & \\
\hline & $\mathrm{N}$ & 106 & & & & & & \\
\hline Budgeting & Pearson Correlation & $.722^{* *}$ & 1 & & & & & \\
\hline \multirow[t]{2}{*}{ System } & Sig. (2-tailed) & .000 & & & & & & \\
\hline & $\mathrm{N}$ & 106 & 106 & & & & & \\
\hline Strategic & Pearson Correlation & $.627^{* *}$ & $.620^{* *}$ & 1 & & & & \\
\hline \multirow[t]{2}{*}{ Analysis } & Sig. (2-tailed) & .000 & .000 & & & & & \\
\hline & $\mathrm{N}$ & 106 & 106 & 106 & & & & \\
\hline Information for & Pearson Correlation & $.672^{* *}$ & $.630^{* *}$ & $.701^{* *}$ & 1 & & & \\
\hline Decision & Sig. (2-tailed) & .000 & .000 & .000 & & & & \\
\hline Making & $\mathrm{N}$ & 106 & 106 & 106 & 106 & & & \\
\hline Performance & Pearson Correlation & $.452^{* *}$ & $.431^{* *}$ & $.466^{* *}$ & $.743^{* *}$ & 1 & & \\
\hline Measurement & Sig. (2-tailed) & .000 & .000 & .000 & .000 & & & \\
\hline System & $\mathrm{N}$ & 106 & 106 & 106 & 106 & 106 & & \\
\hline Contemporary & Pearson Correlation & $.865^{* *}$ & $.818^{* *}$ & $.827^{* *}$ & $.895^{* *}$ & $.727^{* *}$ & 1 & \\
\hline \multirow[t]{2}{*}{ MAP } & Sig. (2-tailed) & .000 & .000 & .000 & .000 & .000 & & \\
\hline & $\mathrm{N}$ & 106 & 106 & 106 & 106 & 106 & 106 & \\
\hline Managerial & Pearson Correlation & $.331^{* *}$ & $.412^{* *}$ & $.488^{* * *}$ & $.502^{* *}$ & $.437^{* *}$ & $.515^{* *}$ & 1 \\
\hline \multirow[t]{2}{*}{ Performance } & Sig. (2-tailed) & .001 & .000 & .000 & .000 & .000 & .000 & \\
\hline & $\mathrm{N}$ & 106 & 106 & 106 & 106 & 106 & 106 & 106 \\
\hline
\end{tabular}

**. Correlation is significant at the 0.01 level (2-tailed). 


\section{Conclusions}

The important aspect of this study is to identify adoption level of costing system, budgeting system, strategic analysis, information decision making and performance measurement amongst co-operatives in Malaysia. The empirical results indicate that co-operatives use contemporary management accounting tools for their planning and management process. As the top 100 co-operatives in Malaysia, mastering in management accounting tools is absolutely key for a manager. Establishing the organizations' strategy requires managers to attract and serve co-operatives to the maximum level. The model for management accounting tools in co-operatives must reveals the strategic terms and corporate identity by outlining the relationship between management accounting tools and managerial performance. This fact is in line with the objectives of management accounting tools itself that is to provide reasonable internal decision making foundation. Managers must use the management accounting information to improve themselves before they choose matters within their organization, which aids management and control of performance functions perform wisely.

This study also supports the idea of having unique base resources as important tools for organization sustainability. The contemporary MAP is a strategic asset for the co-operatives that is valuable, rare, difficult to imitate, and non-substitutable. The exploitation of knowledge and practicality of management accounting practice argues that the co-operatives should look inside the company to find the sources of competitive instead of looking at competitive environment. The significant relationship between contemporary MAP and managerial performance proves that resource based view theory is the dominant perspective to predict performance and explain firm behaviour.

This study contributes to the literature by providing empirical evidence of the fit between contemporary MAP and managerial performance. Furthermore, five constructs (costing system, budgeting system, strategic analysis, information for decision making, performance measurement) individually proven has significant relationship with managerial performance. However, few limitations should be address in considering the result of this study. Firstly, the respondents were mostly from large co-operatives and had been listed as best top 100 co-operatives in Malaysia for 2018. Further investigations shown that their incomes are not less than RM 1 million for accounting year 2018. Secondly, the study findings are based on the top management opinions and number of respondents are small. It is a good time for other researchers to incorporate various methods of data collections such as interview and documents analysis in further studies.

\section{Acknowledgement}

This paper is based on the research project entitled "The adoption and success of contemporary management accounting practices in the Malaysian Co-operatives Sector". The authors would like to extend their gratitude to the Research Management and Innovation Centre (RMIC), Sultan Idris Education University (UPSI) for the University Research Grants (code: 2018-0115-106-01) that helped fund the research.

\section{References}

Abdel-Kader, M., \& Luther, R. (2006). IFAC's Conception of the Evolution of Management Accounting: A Research Note. Advances in Management Accounting, 15, 229-247. https://doi.org/10.1016/S1474-7871(06)15010-8

Abdel-Maksoud, A., Abdallah, W., \& Youssef, M. (2012). An empirical study of the influence of intensity of competition on the deployment of contemporary management accounting practices and managerial techniques in Egyptian firms. Journal of Economic and Administrative Sciences, 28(2), 84-97. https://doi.org/10.1108/10264111211247043

Ambrose, A.O., Etim, I.E., \& Enagu, F.M. (2016). The Role of Community Development Programmes in Poverty Aleviation in Nigeria: Lessons from Onelga, Rivers State, Nigeria. American Journal of Social Sciences and Humanities, 1(2), 72-83.

Ates, A., Garengo, P., Cocca, P., \& Bititci, U. (2013). The development of SME managerial practice for effective performance management. Journal of Small Business and Enterprise Development, 20(1), 28-54. https://doi.org/10.1108/14626001311298402

Aver, B., \& Cadez, S. (2009). Management accountants' participation in strategic management processes: A cross-industry comparison. Journal for East European Management Studies, 14(3), 310-322.

Barney, J. (1997). Gaining and sustaining competitive advantage. Reading, MA: Addison-Wesley.

Barney, J.B., \& Wright, P.M. (1998). On becoming a strategic partner: The role of human resources in gaining competitive advantage. Human Resource Management, 37(1), 31-46. 
Barney, J., Wright, M., \& Ketchen, D.J. (2001). The resource-based view of the firm: Ten years after 1991. Journal of Management, 27(6), 625-641.

Brauers, W.K. (2018). Location theory and multi-criteria decision making: an application of the MOORA method. Contemporary Economics, 12(3), 241-253.

Chand, M., \& Ambardar, A. (2013). Management Accounting Practices in Hospitality and Service Enterprises: A comparative research. Journal of Commerce \& Accounting Research, 2(3), 1-9.

Chenhall, R.H., \& Langfield-Smith, K. (1998). Adoption and benefits of management accounting practice: An Australian study. Management Accounting Research, 9(1), 1-19. https://doi.org/10.1006/mare.1997.0060

Chung, S., \& Su, Y. (2012). Broad scope management accounting system and managerial performance: The impact of role ambiguity and functional difference. African Journal of Business Management, 6(30), 8873-8878. https://doi.org/10.5897/AJBM11.2181

Geldres-Weiss, V.V., Monreal-Pérez, J., Tornavoi-Carvalho, D., \& Tello-Gamarra, J. (2018). A new measure of international product innovation. Contemporary Economics, 12(4), 367-381.

Ghasemi, R., Mohamad, N.A., Karami, M., Bajuri, N.H., \& Asgharizade, E. (2016). The mediating effect of management accounting system on the relationship between competition and managerial performance. International Journal of Accounting and Information Management, 24(3), 272-295. https://doi.org/10.1108/02656710210415703

Hair, J.F., Black, W.C., \& Anderson, R.E. (2010). Multivariate Data Analysis: A Global Perspective (7th ed.). New Jersey, USA: Pearson Education.

Hammad, S.A., Jusoh, R., \& Ghozali, I. (2013). Decentralization, perceived environmental uncertainty, managerial performance and management accounting system information in Egyptian hospitals. International Journal of $\begin{array}{llll}\text { Accounting } \quad \text { Information } & \text { Management, }\end{array}$ https://doi.org/http://dx.doi.org/10.1108/MRR-09-2015-0216

Hansen, D.R., \& Mowenne, M.M. (2007). Managerial Accounting (8th ed.). USA: Thomson South Western.

Hussain, J., Ali, H., Sadik, M., \& Qasim, S. (2017). Procedural Fairness in Restructuring and Layoffs between two Telecom Companies of Pakistan. Global Journal of Social Sciences Studies, 3(2), 101-112.

Ittner, C.D., Larcker, D.F., \& Rajan, M.V. (1997). The choice of performance measures in annual bonus contracts. Accounting Review, 72(2), 231-255. https://doi.org/10.2307/248554

Joshua, O.O. (2016). Hunger and Malnutrition: Review of Copenhagen Consensus Challenge Paper 2004. American Journal of Social Sciences and Humanities, 1(2), 85-99.

Kalkhouran, A.A.N., Rasid, S.Z.A., Sofian, S., \& Nedaei, B.H.N. (2015). A Conceptual Framework for Assessing the Use of Strategic Management Accounting in Small and Medium Enterprises. Global Business and Organizational Excellence, 35(1), 45-54. https://doi.org/10.1002/joe.21644

Kinyuira, D.K. (2015). Influence of the Co-operative Business Model on the sustainable performance of-co-operative enterprises. The International Journal of Co-Operative Management, 7(2), 12-23.

Lau, C.M. (2015). The effects of nonfinancial performance measures on role clarity, procedural fairness and $\begin{array}{llll}\text { managerial performance. } & \text { Pacific }\end{array}$ https://doi.org/10.1108/MRR-09-2015-0216

Leotta, A., Rizza, C., \& Ruggeri, D. (2017). Management accounting and leadership construction in family firms. Qualitative Research in Accounting and Management, 14(2), 189-207. https://doi.org/10.1108/QRAM-09-2015-0079

Mahoney, T.A., Jerdee, T.H., \& Carroll, S.J. (1965). The Job(s) of Management. Industrial Relations, 4(2), 97-110. https://doi.org/10.1111/j.1468-232X.1965.tb00922.x

Marwanto, I.G.G.H. (2019). Regional Autonomic Contribution in Encouraging MSMEs Growth in City of Kediri, East Java, Indonesia. American Journal of Social Sciences and Humanities, 4(2), 407-417.

Mitter, C., \& Hiebl, M.R.W. (2017). The role of management accounting in international entrepreneurship. Journal of Accounting \& Organizational Change, 13(3), 381-409. https://doi.org/10.1108/JAOC-02-2016-0006

Ngara, C.O. (2017). America's Global Hegemony since the Collapse of the Soviet Union: Implications for Africa's 
Development. Global Journal of Social Sciences Studies, 3(2), 113-121.

Nunnally, J., \& Bernstein, I. (1994). Psychometric Theory (3rd ed.). New York: McGraw Hill.

Oboh, C.S., \& Ajibolade, S.O. (2017). Strategic management accounting and decision making: A survey of the Nigerian Banks. Future Business Journal, 3(2), 119-137. https://doi.org/10.1016/j.fbj.2017.05.004

Pavlatos, O., \& Paggios, I. (2008). Management accounting practices in the Greek hospitality industry. Managerial Auditing Journal, 24(1), 81-98. https://doi.org/10.1108/02686900910919910

Rumelt, R.P. (1991). How much does industry matter? Strategic Management Journal, 12(3), 167-185. https://doi.org/10.1002/smj.4250120302

Santos, A.C. dos, Lavarda, C.E.F., \& Marcello, I.E. (2014). The relationship between cost management knowledge and budgetary participation with managers' performance. Review of Business Management, 16(50), 124-142. https://doi.org/10.7819/rbgn.v16

Subair, R.E., \& Oriogu, C.D. (2016). Still an Issue: The Use of Electronic Books in University Libraries in Nigeria. American Journal of Social Sciences and Humanities, 1(2), 67-72.

Usman, E., Faculty, E., Usman, A., Faculty, B., Sulawesi-indonesia, S., \& Faculty, E. (2016). Leadership Styles in Budgeting Participation To. International Journal of Organizational Innovation, 8(4), 251-260.

Wernerfelt, B. (1984). A resource-based of the firm. Strategic Management Journal, 5, 171-180.

Wu, J., Boateng, A., \& Drury, C. (2007). An analysis of the adoption, perceived benefits, and expected future emphasis of western management accounting practices in Chinese SOEs and JVs. International Journal of Accounting, 42(2), 171-185. https://doi.org/10.1016/j.intacc.2007.04.005

Yigitbasioglu, O.M. (2017). Drivers of management accounting adaptability: the agility lens. Journal of Accounting \& Organizational Change, 13(2), 262-281. https://doi.org/10.1108/JAOC-12-2015-0092 